\title{
Environmental Change and Human Mobility: Trends, Law and Policy
}

\author{
Susan F. Martin
}

\begin{abstract}
Enhancing the protection of persons displaced by natural disasters and the impacts of climate change will require sustained attention. This article identifies practical solutions, many of which are currently under consideration by governments and international organizations, to improve the lives of millions of people affected by environmental crises. It begins with a brief overview of why people move, the nature of those movements, and the relationship between human mobility and adaptation to environmental change by highlighting three types of mobility - migration, displacement and planned relocation. Next, the international and regional level will be discussed, with particular focus on legislative and policy frameworks for addressing human mobility in the context of environmental change. The article identifies gaps in existing frameworks as well as recent efforts to address them, particularly through mini-multilateral initiatives aimed at identifying principles and practices that should guide governmental action. The article concludes that efforts to improve responses require a better evidence base than currently exists on issues such as the environmental determinants of migration, displacement and planned relocation; the multi-faceted ways in which environmental factors relate to the many other causes of population movements in the cases of human mobility; and the impact of such movements on the well-being of migrants, communities of origin, and communities of destination.
\end{abstract}

Keywords: Migration · Environmental change $\cdot$ Displacement $\cdot$ Planned relocation

\section{Introduction}

The environment is but one of many reasons that prompt people to move, sometimes operating on its own but more often through other mechanisms, particularly loss of livelihoods affected by environmental disruption (see for example, Black et al. 2011; Etzold et al. 2014; Foresight Project 2011; Ginetti 2015; Hugo 2011; Kniveton et al. 2011; White 2011). Nevertheless, there has also been growing recognition that 
climate change poses profound consequences for human mobility. According to the Fifth Assessment Report of the Intergovernmental Panel on Climate Change (IPCC), "climate change over the $21^{\text {st }}$ century is projected to increase displacement of people" (IPCC 2014: 20). The IPCC's detailed review of the evidence indicated that "[e]xtreme weather events provide the most direct pathway from climate change to migration" but in the longer term, "sea level rise, coastal erosion, and loss of agricultural productivity (...) will have a significant impact on migration flows" (Adger et al. 2014: 767-769).

The human consequences - including on mobility - have not escaped the attention of governments, international organizations and civil society. In 2010, the Conference of the Parties to the UN Framework Convention on Climate Change (COP) adopted the Cancun Adaptation Framework, which called on all countries to take "measures to enhance understanding, coordination and cooperation with regard to climate change induced displacement, migration and planned relocation, where appropriate, at national, regional and international levels." The resolution reflected growing awareness that environmental change, and climate change ${ }^{1}$ in particular, was already having a profound impact on the mobility of people and was likely to have still more impacts in the years ahead. In addressing human mobility, the resolution differentiated between displacement, migration and planned relocation, setting out three markedly different responses to environmental processes and events. This article uses "mobility" to encompass the three different forms of movement and "migration", "displacement" and "planned relocation" when specific forms of mobility are discussed. ${ }^{2} \mathrm{~A}$ working description of each group is provided in the next section.

In Doha in 2012, the COP reiterated the need for more attention to human mobility within the context of loss and damage, noting the need for greater understanding of "how impacts of climate change are affecting patterns of migration, displacement and human mobility (UNFCCC 2012: 23)." In this regard, loss refers to the "inability to respond to climate stresses (i.e. the costs of inaction)", whereas damage is defined as "costs associated with existing coping and adaptive strategies (cf. erosive coping strategies and mal-adaptation)" (Warner et al. 2012). The COP 21, which took place in Paris in 2015, requested "the Executive Committee of the Warsaw International

1 Environmental changes include a broader understanding of hazards and processes than encompassed by climate change. Examples of the former include earthquakes and human-made environmental degradation and destruction, such as nuclear and industrial accidents. Climate change includes rising sea levels, drought, cyclones and other weather-related events.

2 In contrast to refugees, who are defined in international law, there are no legal definitions of migration, displacement or planned relocation. The closest is a working definition provided by the International Organization for Migration (IOM) of environmental migration: "Environmental migrants are persons or groups of persons who, for compelling reasons of sudden or progressive changes in the environment that adversely affect their lives or living conditions, are obliged to leave their homes or choose to do so, either temporarily or permanently, and who move either within their country or abroad (IOM 2007)." This definition is so broad, however, that it encompasses displacement and planned relocation under the rubric of migration, making it difficult to distinguish among the forms of movement. 
Mechanism $^{3}$ to establish, according to its procedures and mandate, a task force (...) to develop recommendations for integrated approaches to avert, minimize and address displacement related to the adverse impacts of climate change (UNFCCC 2016: 8)." Although it did not specify the form that the recommendations are to take, the statement indicated that the work of the taskforce should "complement, draw upon the work of and involve, as appropriate, existing bodies and expert groups under the Convention including the Adaptation Committee and the Least Developed Countries Expert Group, as well as relevant organizations and expert bodies outside the Convention (UNFCCC 2016: 8)." This directive represented the first attempt by the UNFCCC process to develop concrete recommendations on ways to address an important form of human mobility associated with climate change.

Progress is also being made in developing guidance for states on ways to enhance protection of those who move in the context of environmental change. These efforts stem from broad recognition that current legal and institutional frameworks do not apply in many of the situations arising when people move as a result of natural disasters or the slow-onset effects of climate change. Two state-led initiatives are paving the way for rethinking the policy frameworks that apply in these cases: The Nansen Initiative for cross border displacement from natural disasters and climate change, and the Migrants in Countries in Crisis (MICIC) initiative for nonnationals already in countries experiencing natural disasters (and conflict). These initiatives are being driven by states themselves, rather than international organizations, academic institutions or nongovernmental agencies. As such, they represent a commitment from states to formulate principles and guidelines to address a compelling issue.

The following sections present a brief overview of why people move, the nature of those movements, and the relationship between human mobility and adaptation to environmental change. It highlights the three types of mobility - migration, displacement and planned relocation - discussed in the Cancun Adaptation Framework. The article then turns to responses at the international and national levels, with particular focus on legislative and policy frameworks for addressing human mobility in the context of environmental change. It seeks to identify gaps in existing legal and institutional frameworks. The next section examines the Nansen and $\mathrm{MICIC}$ initiatives in greater depth. Finally, the conclusion explains why the author is cautiously optimistic about these mechanisms and the potential for more effective responses.

3 The UNFCCC established the Warsaw International Mechanism for Loss and Damage associated with Climate Change Impacts in 2013 "to address loss and damage associated with impacts of climate change, including extreme events and slow onset events, in developing countries that are particularly vulnerable to the adverse effects of climate change." See http://unfccc.int/ adaptation/workstreams/loss_and_damage/items/8134.php for additional information. 


\section{Setting the Stage}

This section provides an overview of the determinants of movements, forms of mobility, and the role of mobility in regard to adaptation to environmental risks and changes.

\subsection{Determinants of Mobility in the Context of Environmental Change}

The report of the UK Foresight Project (2011) provides an excellent framework for identifying the factors that help determine not only whether people move but also when and where they go (see Fig. 1). The chart includes macro level factors, demonstrating the multiple drivers of movement (economic, social, political, demographic as well as environmental). However, these drivers alone will not necessarily result in the movement of people. The decision to migrate or stay is also influenced by personal and household demographic and socio-economic characteristics as well as intervening obstacles and facilitators that determine whether movement is feasible. Household vulnerability and resilience to environmental changes - that is, the capability to cope with or adapt to them - often determines the degree to which people need to move and their ability to get out of harm's way. The most vulnerable populations may well be those who are trapped in fragile eco-systems, unable to support themselves and unable to move to places of greater safety and opportunity. The mix of all of these determinants that lead to the decision to move or to stay makes research on the determinants of mobility resulting from environmental change a complex endeavor.

Fig. 1: Drivers of International Migration

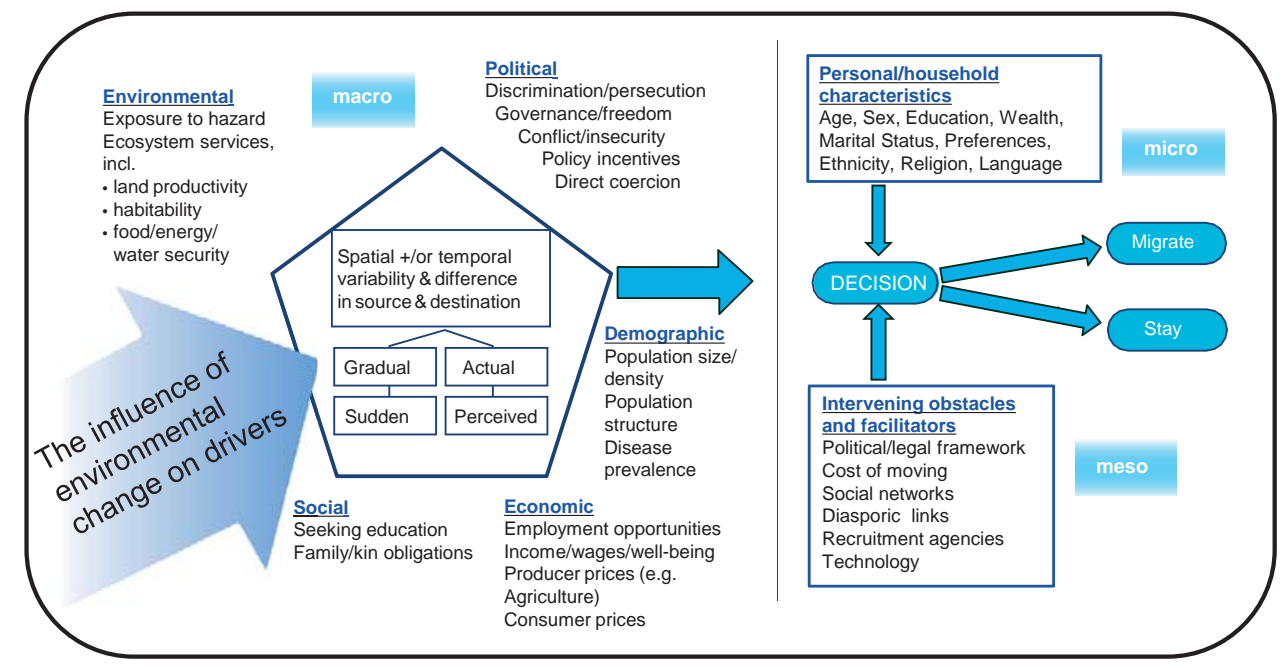

Source: Foresight Project: Migration and Global Environmental Change 2011 
Within this context, research is converging on the role that climate change is likely to play in accord with these other factors. As discussed above, the IPCC's review of the literature concludes that climate change will indeed play an important role in future movements, potentially even more than in the past. More specifically, there are four paths by which climate change may affect human movement either directly or, more likely, as per Foresight, in combination with other factors:

- Changes in weather patterns that contribute to longer-term drying trends that affect access to essential resources such as water and negatively affect the sustainability of a variety of environment-related livelihoods including agriculture, forestry, fishing, etc. Those most affected by drought may, however, have lower levels of migration if the drying pattern reduces household income so that they are unable to move (see, for example, Bylander 2016; Gray/Mueller 2012; Jülich 2011).

- Rising sea levels and glacier melt cause massive and repeated flooding and render coastal and low-lying areas uninhabitable in the longer-term (Warner/van Geest 2013; de Sherbinin et al. 2011; Wrathall 2012; Dun 2011; Shen/Gemenne 2011).

- Increased frequency and magnitude of weather-related acute natural hazards, such as hurricanes and cyclones, which already destroy infrastructure and livelihoods and require people to relocate for shorter or longer periods (IFRC 2012; Adger et al. 2014). As climate change intensifies these events, even more people will be at risk.

- Competition over natural resources that may exacerbate pressures contributing to conflict, which in turn precipitates movements of people. Prolonged drought appears to have exacerbated tensions in Syria, contributing to the 2011 demonstrations against the Assad regime, which in turn led to the protracted conflict that has displaced millions of people (Kelley et al. 2015). Conflict also clearly makes it more difficult to address the needs of climate-change affected populations, as witnessed in Somalia in 2011, during the severe drought in the Horn of Africa. Only Somalia among the drought affected areas experienced high levels of famine and displacement. ${ }^{4}$ In 2017, the UN High Commissioner for Refugees (UNHCR) warned of the widespread threat of famine in South Sudan, Nigeria and Yemen if there is an escalation of the ongoing conflicts in these countries (UNHCR 2017).

It is important to note that drivers of mobility include not only factors at work in source communities and countries that may push people to leave their homes. They also include pull factors in potential areas of destination that make them attractive destinations. As the Foresight diagram indicates, both actual and perceived differences between conditions in source and destination communities are likely to influence mobility.

4 See UNHCR statistics at http://www.unhcr.org/en-us/statistics/country/516282cf5/unhcr-statistical-yearbook-2011-11th-edition.html. 


\subsection{Forms of Mobility}

The Foresight figure also captures gradual and sudden onset drivers, which can in turn influence gradual or sudden movements. The first two scenarios - longerterm drought and rising sea levels - are likely to cause slow-onset migration, in which people seek new homes and livelihoods over a lengthy period as conditions in their home communities worsen. In many cases, this migration is voluntary and is a strategy to reduce the risk of being exposed to current and future shocks. Migrants seeking to avoid such environmental changes may resemble labor migrants, seeking better livelihood opportunities in a new location. This will especially occur if people move in anticipation of worsening conditions, rather than as a direct reaction to the changes taking place. The third and fourth scenarios - acute natural hazards and conflict - are likely to create conditions that cause large-scale displacement, often in the context of emergencies. In these situations, those who move may resemble refugees and internally displaced persons who have fled situations beyond their individual control. The movements will likely involve displacement of entire communities who will often move en masse to new locations with little or no warning. In both cases, there may be individuals and households who are unable or unwilling to leave even in the face of life-threatening situations. For them, planned relocation may be needed. These two forms of environmental hazard (acute and slow onset) and their resulting patterns of movement (migration, displacement and planned relocation) need to be assessed separately to determine the appropriate policy responses and program requirements.

In both slow onset and acute cases, movement may be temporary, cyclical or permanent. The decision as to whether return is possible involves a range of variables, including the extent to which the environmental causes - either direct or through other channels - is likely to persist or frequently reoccur. Policies in the receiving communities and countries, depending on whether the movement is internal or international, will also affect the likelihood for return or settlement in the new location. In addition to immigration policies, the policies affecting return and settlement include land use and property rights, social welfare, housing, employment, and other frameworks that determine whether individuals, households, and communities are able to find decent living conditions and pursue adequate livelihoods. Return and reintegration is also affected by plans and programs to mitigate future dislocations from environmental hazards.

Different types of environmental stressors also affect the destinations of those who move. Many experts believe that most mobility in the context of environmental change will be domestic (except for low-lying small island states without higher elevation) or immediately cross-border. Such migration may be particularly challenging as the receiving communities and countries will likely have few resources, legal structures, or institutional capacity to respond to the needs of the migrants. Geographical proximity may also mean that destination areas face some of the same environmental challenges as areas of migration origin (e.g. drought, desertification) and may offer little respite in this regard. Some long-distance movements are inevitable given the scope of migration today, as witnessed by the attempt of many 
Syrian and other asylum seekers to reach Europe. It is important to keep in mind, however, that there are about 6 million internally displaced persons (IDPs) in Syria itself and about five million Syrian refugees in Jordan, Lebanon and Turkey. The numbers attempting to enter Europe are much smaller by comparison, estimated at about 1.3 million in 2015 (Connor 2016).

\subsection{Mobility and Adaptation}

As discussed above, the Cancun Adaptation Framework adopted language that placed mobility firmly on the climate-change adaptation agenda. Largely because of the complexities in mobility patterns discussed above, the Cancun Framework outlined three different forms of mobility - migration, displacement and planned relocation.

Climate adaptation strategies related to mobility fall into two major categories: First, and more commonly, governments view adaptation to climate change as a way to reduce emigration pressures and allow people to remain where they are by modifying agricultural practices, management of pastoral lands, infrastructure such as dykes and coastal barriers, fishing patterns and other strategies to reduce pressures on fragile eco-systems.

Second, movement of people to other locations may instead be seen as an adaptation strategy itself by climate change-affected countries (Stojanov et al. 2014; Martin 2012; Geddes/Somerville 2013; Rademacher-Schulz et al. 2014). Some countries see migration as a way to reduce population pressures in places with fragile eco-systems; others recognize that resettlement of some populations may be inevitable, but should be accomplished with proper planning. Moreover, people already living outside vulnerable areas may be important resources to help communities adapt and respond to climate change, a perspective that is of particular interest to development policy makers. Just as migrants are contributing to the broader development of their home countries, such strategies envision that the diaspora may have the technical knowledge and financial resources to help communities cope with the effects of climate change. Finally, in the absence of appropriate relocation strategies, populations that should be moved away from hazardous situations may be trapped in place, unable to leave on their own.

Even countries facing similar climate changes differ in the extent to which they focus on the interconnections between human mobility and adaptation and the ways in which they understand the relationship. Smith and MacNamara (2014) note the different approaches of Tuvalu and Kiribati to the prospect of relocation of large numbers of their citizens. They refer to Tuvalu's approach as preventative action to avoid migration: "The migration issue was not wholly denied as a possible future scenario for Tuvalu but this appears to be something that would only be considered in the case of a tsunami or similar disaster event, rather than the progressive incremental environmental degradation of the islands" (Smith/MacNamara 2014: 53). By contrast, Kiribati views migration as an "active policy option," reflecting frustration at the slow pace of international negotiations regarding the mitigation of climate change (Smith/MacNamara 2014: 55). 
Research is scarce on both issues - the efficacy of strategies to reduce emigration pressures, and the impacts of different forms of mobility on those who move and communities of origin and destination when used as an adaptation strategy. Interdisciplinary research will likely be needed, engaging the expertise of researchers familiar with agriculture, fishing, infrastructure, land use and tenure and other relevant issues as well as those who understand the determinants of migration. Strategies that focus on specific environmental responses that do not take into account the other macro, meso and micro factors discussed above are unlikely to be effective in influencing mobility. Similarly, research on the strengths and weaknesses of these approaches will need to consider multiple variables in assessing the efficacy of the adaptation strategies. As many of these strategies are still in the planning stage, thinking through what factors to consider in evaluations is essential.

A new body of research is beginning to assess the impact of mobility as an adaptation strategy. The Rainfalls project, for example, posits four likely outcomes of mobility for those who move as well as their families left behind: (1) some families will prosper as a result of movements; (2) others will survive but not be materially better off; (3) still others will be worse off having left their home communities; and (4) a final group will be trapped in place unable to leave their homes (Warner/Afifi 2014). These are far from self-evident since a range of factors, including pre-existing levels of resilience and vulnerability, as well as the forms of movement that take place, determine which impacts are experienced by households and even entire communities.

Research to replicate or challenge these findings in other locations and with other environmental drivers would help expand the understanding of the potentially multiple impacts of mobility on those most affected by environmental change. Similarly, understanding the impacts derived from different forms of movement would help identify the strengths and weaknesses of adaptation strategies themselves. For example, more evidence is needed to determine if those who move voluntarily in anticipation of environmental harm show greater capacity to improve their situation than those who are spontaneously displaced or forced to participate in planned relocation programs. Third parties (e.g., humanitarian and development) may offset some of the harms that might otherwise occur when people are forced to leave home but there is little evidence as to best practices in this area.

Since a number of governments, including those as different as small island countries in the Pacific and the United States, are considering planned relocation of their citizens from environmentally hazardous areas to new sites, learning the lessons from development projects involving relocation - such as hydroelectric dams - is imperative. ${ }^{5}$ Research on these projects has raised many questions about their impacts on the resettled groups, many of whom were worse off after relocation than they had been previously (Cernea 1997, 2005). In 2001, the World Bank adopted guidelines on involuntary resettlement to address some of the more egregious

5 See case studies referenced in Georgetown University et al. (2016) for further examples. 
actions. ${ }^{6}$ UNHCR, the Brookings Institution and Georgetown University developed guidance on planned relocation in the context of natural disasters and environmental change that would improve the protection of those who are relocated as well as the communities into which they move, as discussed below (Brookings Institution et al. 2015; Brookings Institution et al. 2014; Georgetown University et al. 2016).

\section{$3 \quad$ Legal and Policy Gaps}

This section discusses legal and policy frameworks for protecting those who move in the context of environmental change. It highlights gaps in current law and policy with regard to both internal and cross-border movements. It focuses on international and regional law as well as national policies.

\subsection{Internal Movements}

Internal mobility is a matter of state sovereignty. The limits of sovereignty are not absolute, however. The Universal Declaration of Human Rights provides clear guidance in Article 13 that "everyone has the right to freedom of movement and residence within the borders of each state." Article 12 of the International Covenant on Civil and Political Rights (ICCPR) affirms that "Everyone lawfully within the territory of a State shall, within that territory, have the right to liberty of movement and freedom to choose his residence." The ICCPR provides certain exceptions: "The abovementioned rights shall not be subject to any restrictions except those which are provided by law, are necessary to protect national security, public order (ordre public), public health or morals or the rights and freedoms of others, and are consistent with the other rights recognized in the present Covenant." To the extent that climate change produces conditions that undermine national security, public order or public health, which may be the case in extreme natural disasters or conflict, then governments would have the right to enact provisions that would require people to move.

A further relevant framework are the Guiding Principles on Internal Displacement and the African Union Convention for the Protection and Assistance of Internally Displaced Persons in Africa. The Guiding Principles are not legally binding, but many states have adopted them into national law. They describe internally displaced persons or groups of persons as those "who have been forced or obliged to flee or to leave their homes or places of habitual residence, in particular as a result of or in order to avoid the effects of armed conflict, situations of generalized violence, violations of human rights or natural or human-made disasters, and who have not crossed an internationally recognized State border." The AU Convention, which went into force in 2012, explicitly recognizes that there will likely be displacement from climate change, stating in Article 4: "States Parties shall take measures

6 See the guidelines at https://policies.worldbank.org/sites/ppf3/PPFDocuments/090224b0822 f89db.pdf. 
to protect and assist persons who have been internally displaced due to natural or human made disasters, including climate change."

The Guiding Principles affirm that all persons have the "right to be protected against being arbitrarily displaced from his or her home or place of habitual residence." In the case of climate change-induced displacement, arbitrary displacement would include situations in which individuals are forced to flee for reasons that "are not justified by compelling and overriding public interests". In the case of natural disasters, such displacement is arbitrary, "unless the safety and health of those affected requires their evacuation". The Guiding Principles also state that "the authorities concerned shall ensure that all feasible alternatives are explored in order to avoid displacement altogether. Where no alternatives exist, all measures shall be taken to minimize displacement and its adverse effects."

The Guiding Principles emphasize the need for consultation with the affected parties, stating that the free and informed consent of those to be displaced shall be sought. The authorities responsible for displacing persons are encouraged to involve those affected, particularly women, in the planning and management of their relocation. In particular, care should be taken to ensure that "proper accommodation is provided to the displaced persons, that such displacements are effected in satisfactory conditions of safety, nutrition, health and hygiene, and that members of the same family are not separated."

\subsection{International Mobility}

States possess broad authority to regulate the movement of foreign nationals across their borders. Although these authorities are not absolute, states exercise their sovereign powers to determine who will be admitted and for what period. The authority of states is limited by certain rights accorded foreign nationals in international law. There are no international instruments that specifically address international movements stemming from environmental factors. Those moving because of environmental factors have the same rights and responsibilities as others who cross international borders. The Universal Declaration of Human Rights (UDHR), the ICCPR and the International Covenant on Economic, Social and Cultural Rights (ICESCR) define the basic rights of all persons. Importantly, UDHR Article 13 also declares that "everyone has the right to leave any country, including one's own, and to return to one's own country." The Declaration does not, however, require any other country to admit people who exercise their right to leave. Similarly, UDHR Article 14 states that "everyone has the right to seek and to enjoy in other countries asylum from persecution," but there is no corresponding obligation on the part of states to offer asylum. The obligation, as discussed below, is not to forcibly return someone to where they face a well-founded fear of persecution.

There are no legally binding conventions that apply specifically to persons whose displacement is correlated with climate change. The UN Convention on the Protection of All Migrant Workers and Members of their Families would apply if those who move enter the labour market in a host country. There are no specific provisions, however, within the Migrant Workers Convention for those moving because of envi- 
ronmental factors compared to any other reasons. Some may be covered under the 1951 UN Convention Relating to the Status of Refugees and its 1967 Protocol. ${ }^{7}$ The Convention defines refugees as persons who were unable or unwilling to avail themselves of the protection of their home countries because of a "well-founded fear of persecution based on their race, religion, nationality, political opinion or membership in a particular social group." While few persons seeking protection because of purely environmental reasons are likely to meet the definition, those fleeing from the impacts of climate change may qualify if their lives are in danger because they are unable to access resources because of a protected characteristic (that is, race, religion, nationality, membership of a particular social group or political opinion).

In Africa, the scope of coverage might be greater because the 1969 OAU (now AU) Refugee Convention includes those who, "owing to external aggression, occupation, foreign domination or events seriously disturbing public order in either part or the whole of his country of origin or nationality (emphasis added), is compelled to leave his place of habitual residence in order to seek refuge in another place outside his country of origin or nationality." The Cartagena Declaration, adopted by Latin American countries in 1984, has a similar broadening of the refugee definition to include "among refugees persons who have fled their country because their lives, safety or freedom have been threatened by (...) other circumstances which have seriously disturbed public order," but it is not binding regional law. To the extent that the impacts of environmental change seriously disturb public order, persons forced to leave their homes may be covered under these instruments (Lopez 2007). ${ }^{8}$

The immigration policies of most destination countries are not conducive to receiving large numbers of environmental migrants, unless they enter through already existing admission categories. Typically, destination countries admit persons to fill job openings or to reunify with family members. Employment-based admissions are usually based upon the labour market needs of the receiving country, not the situation of the home country. Family admissions are usually restricted to persons with immediate relatives (spouses, children, parents and, sometimes, siblings) in the destination country.

Humanitarian admissions are generally limited to refugees and asylum seekers - that is, those who fit the definition in the UN Convention Relating to the Status of Refugees: persons with a well-founded fear of persecution on the basis of race, religion, nationality, membership in a particular social group or political opinion. As is the case regarding international law, most people moving because of environmental harm will be unlikely to meet the legal definition of a refugee, forced to flee because

7 The protocol eliminated geographic (that refugees be from Europe) and time (pre-1951) limits on the Convention, making it a universal document.

Lopez (2007: 390) acknowledges that the "International Conference on Central American Refugees (CIREFCA) report interpreting the Cartagena Declaration distinguishes, however, between 'victims of natural disasters' and other events 'seriously disturbing the public order,' and observes that the former do not qualify as refugees." While Cartagena may not apply in natural disasters, it could apply in human-made environmental crises that result in serious disruptions of public order. 
of loss of livelihood or habitat and not because of persecutory policies. A New Zealand case highlights the barriers to refugee claims based on the effects of climate change. A Kiribati citizen who had overstayed his visa applied for asylum citing the effects of climate change on his home country. The Supreme Court of New Zealand held in 2015 that "[i]n relation to the Refugee Convention, while Kiribati undoubtedly faces challenges, Mr Teitiota does not, if returned, face 'serious harm' and there is no evidence that the Government of Kiribati is failing to take steps to protect its citizens from the effects of environmental degradation to the extent that it can." ${ }^{\prime 9}$ The court did not rule out that another case involving serious environmental harm from climate change might meet the persecution bar for refugee status. Presumably, if a country were to protect some of its nationals from environmental harm while allowing others to suffer because of their race, religion, nationality, membership in a particular social group or political opinion, a claim to asylum might be appropriate.

Despite the lack of law and formal policies, governments respond frequently, albeit mostly in an ad hoc way, to those who have been displaced by natural hazards. The 2010 earthquake in Haiti provides a good example of humanitarian admissions policies that were used by governments to protect persons not already on their territory and who did not qualify as refugees. The Dominican Republic responded almost immediately, permitting an estimated 160,000 Haitians to cross onto its territory. Many of those permitted entry had been seriously injured and required medical care. Family members were also allowed to enter the Dominican Republic to stay with the injured during their convalescence (Weiss Fagen 2013).

Other Haitians received humanitarian visas to enter Brazil. At first, the Haitians applied for asylum but the Brazilian government determined that they did not fit the refugee definition. Also recognizing that they were not seeking admission for purely economic reasons, Brazil offered the alternative of humanitarian visas. Initially, the determinations were made at the border. Thousands of Haitians had travelled to Ecuador, which had suspended visa requirements for Haitians in 2008, and then made their way to the Brazilian border. Subsequently, Brazil instituted processing procedures in Haiti for persons seeking humanitarian admissions. At first, these were for temporary admissions but Brazil now has a category for permanent admissions. In September 2015, the IOM established the Brazil Visa Application Centre (BVAC) to facilitate applications for these visas.

Countries such as Canada and the United States sped up the entry of persons who had already applied for admission, recognizing that they would remain in lifethreatening situations if forced to wait for their turn in the admissions queue. For Canada, for example, "this meant expediting and to some extent stretching the existing immigration categories through which Haitians would be eligible to come to Canada without changing existing immigration rules and regulations." These applied primarily to family reunification applications. The province of Quebec, which controls its own immigration policy, expanded its notion of family reunification to

9 loane Teitiota, Applicant and the Chief Executive of the Ministry of Business, Innovation And Employment, Respondent, Supreme Court of New Zealand, SC 7/2015 [2015] NZSC 107. 
include "formerly inadmissible categories of adult brothers and sisters, step brothers and sisters and adult children, along with their own families." As a result, Quebec admitted about 9,000 Haitians in 2010 alone.

Governments also have applied policies for deferral of deportation of those displaced by natural disasters. These range from statutory measures to ad hoc ones. One of the most well-developed statutory provisions is in U.S. legislation enacted in 1990 to provide temporary protected status to persons "in the United States who are temporarily unable to safely return to their home country because of ongoing armed conflict, an environmental disaster, or other extraordinary and temporary conditions." ${ }^{10}$ Environmental disaster may include "an earthquake, flood, drought, epidemic, or other environmental disaster in the state resulting in a substantial, but temporary, disruption of living conditions in the area affected." ${ }^{10}$ In the case of environmental disasters, as compared to conflict, the country of origin must request designation of TPS for its nationals.

Importantly, TPS only applies to persons already in the United States at the time of the designation. It is not meant to be a mechanism to respond to an unfolding crisis in which people seek admission from outside of the country. It also only pertains to situations that are temporary in nature. On the other hand, countries are often re-designated and "temporary" protection is offered to their nationals over lengthy periods. For example, TPS was originally triggered in 1999 in the wake of Hurricane Mitch, which had severe impacts on Nicaragua and Honduras. Its most recent extension is until January 5, 2018. Those granted TPS are left in limbo throughout these periods; they are unable to become permanent residents unless they meet the criteria of other immigration statuses (e.g., they have married a U.S. citizen).

If the environmental disaster has permanent consequences, however, a designation of Temporary Protected Status is not available or it may be lifted. When a volcano erupted in Montserrat in 1997, TPS was granted to its citizens and was extended six times. In 2005, however, it was ended because "it is likely that the eruptions will continue for decades, [and] the situation that led to Montserrat's designation can no longer be considered 'temporary' as required by Congress when it enacted the TPS statute."

Another significant factor is that the designation is discretionary, to be made by the Secretary of Homeland Security. Countries or parts of countries are designated, allowing nationals only of those countries to apply. Notably, TPS was not triggered for the hurricanes that destroyed large parts of Haiti but was offered following the 2010 earthquake and has since been extended.

Sweden and Finland have also included environmental migrants within provisions of their immigration policies. Sweden includes within its asylum system persons who do not qualify for refugee status but have need for protection. Such a person in need of protection "has left his native country and does not wish to return there because he: [1] has a fear of the death penalty or torture [2] is in need of pro-

10 Immigration and Naturalization Act Sec. 244. 1/ [8 U.S.C. 1254] https://www.uscis.gov/ilink/ docView/SLB/HTML/SLB/0-0-0-1/0-0-0-29/0-0-0-7238.html. 
tection as a result of war or other serious conflicts in the country [3] is unable to return to his native country because of an environmental disaster." The decision is made on an individual basis. Although many prospective recipients of this status are presumed to be in temporary need of protection, the Swedish rules foresee that some persons may be in need of permanent solutions. Similarly, in the Finnish Aliens Act, "aliens residing in the country are issued with a residence permit on the basis of a need for protection if [...] they cannot return because of an armed conflict or environmental disaster."

A number of other countries provide exceptions to removal on an ad hoc basis for persons whose countries of origin have experienced significant disruption because of natural disasters. After the 2004 Indian Ocean tsunami, for example, Switzerland, United Kingdom and Canada suspended deportations of those from such countries as Sri Lanka, India, Somalia, Maldives, Seychelles, Indonesia and Thailand. A number of governments announced similar plans after the 2010 earthquake in Haiti.

To date, there are no examples of legislation or policies that address migration or relocation of persons from slow onset climate changes that may destroy habitats or livelihoods in the future. ${ }^{11}$ For the most part, movements from slow onset climate change and other environmental hazards that limit economic opportunities are treated in the same manner as economically motivated migration. Persons moving outside of existing labour and family migration categories are considered to be irregular migrants. In the absence of a strong humanitarian basis for exempting them from removal proceedings (which is unlikely in the slow onset situation), these migrants would be subject to the regular systems in place for mandatory return to their home countries. As their immediate reasons for migrating would be similar to that of other irregular migrants - that is, lack of economic opportunities at home and better economic opportunities abroad - there would be little reason for destination countries to manage these movements outside of their existing immigration rules.

There are also no binding international instruments governing the rights of those who are relocated because of the impacts of environmental change or the responsibilities of governments in requiring or supporting such actions. Recognizing the gap, UNHCR, in collaboration with the Brookings Institution and Georgetown University and the support of the European Commission, launched a project in 2011 to develop guidance in this area. The project focused only on planned relocation within affected countries, leaving discussion of cross-border relocation to the Nansen Initiative (see below). As the Cancun Framework did not define planned relocation, the first task was to offer a definition:

11 New Zealand's Pacific Access Category (PAC), under which 75 people from Tuvalu, 75 from Kiribati, and 250 from Tonga may immigrate to New Zealand each year, is sometimes described as climate change related legislation. The program is based on employment, however, not environmental factors. The immigrants must be between $18-45$ years old, have an offer of employment in New Zealand, have English skills, meet minimum income requirement, undergo a health check, and have no history of illegal entrance. 
Planned Relocation is (...) a planned process in which persons or groups of persons move or are assisted to move away from their homes or places of temporary residence, are settled in a new location, and provided with the conditions for rebuilding their lives. Planned Relocation is carried out under the authority of the State, takes place within national borders, and is undertaken to protect people from risks and impacts related to disasters and environmental change, including the effects of climate change. Such Planned Relocation may be carried out at the individual, household, and/or community levels (Brookings Institution et al. 2015: 9).

The Guidance then sets out core principles: Planned relocation should be "undertaken for the benefit of Relocated Persons and in a manner that respects and protects their rights and dignity" (Brookings Institution et al. 2015: 10). Generally, planned relocation is a measure of last resort when other disaster risk reduction or adaptation options fail. As such, "states must have compelling reasons, robust evidence, and a sound legal basis for undertaking Planned Relocation" (Brookings Institution et al. 2015: 11). Those most affected by planned relocation - the relocated and other affected communities ${ }^{12}$ - should be consulted. And, every effort should be made to enable relocated persons "to improve, or, at a minimum restore, their living standards" and host populations "to maintain their pre-existing living standards, or to attain the same living standards as relocated persons, whichever is higher." This last principle is important because too often, involuntary resettlement in the context of major construction projects has resulted in lowered standards of living as well as economic, social and cultural loss (Cernea 1997; DeWit 2006). ${ }^{13}$ From principles, the guidance moves to practical approaches to protect those affected by relocation in the pre-, during- and post-relocation phases. It emphasizes the need for states, as the entities with principal responsibility for planned relocation, to develop and enact the legal and policy basis for undertaking these programs; establish the institutional framework for carrying them out as well as the criteria for making decisions throughout a planned relocation; put in place an impartial and equitable grievance, review, conflict resolution, and redress mechanisms; provide for timely, sufficient, and sustainable funding; and ensure planned relocation is incorporated into other intersecting and crosscutting issues and activities, including development and land-use frameworks (Brookings Institution et al. 2015). The guidance was derived from consultations with experts from within and outside government in multiple fields: development, environment, humanitarian efforts, human rights, migration and refugees, disaster risk reduction and adapta-

12 Other affected persons include host populations, persons who choose not to take part in planned relocation, and persons who live in close proximity to the communities to be relocated but who do not qualify for relocation. The second and third group may be affected by the relocation if services, infrastructure and/or markets are relocated along with people.

13 In his seminal 1997 work, Cernea lists 8 harms from involuntary resettlement: (a) landlessness; (b) joblessness; (c) homelessness; (d) marginalization: (e) food insecurity; (f) loss of access to common property resources; (g) increased morbidity; (h) community disarticulation. Many of these problems persist as examined in a 2015 special issue of Development in Practice (25.5) on development-induced displacement and involuntary resettlement in Asia. 
tion. The current phase of the project involves consultation with states and other stakeholders and the development of more operational guidance to promote effective implementation. It has also taken on new partners, including the IOM and UN University's Institute for Environment and Human Security.

\section{$4 \quad$ Organizational Arrangements}

Just as the international legal frameworks for addressing climate change-induced movements are weak, so are the institutional roles and responsibilities at both the international and the national levels. With the exception of the refugee regime, in which clear responsibility is given to UNHCR, there is no existing international regime for managing international movements of people. This is not to say that there is a total absence of governance. There are a plethora of international organizations that have some responsibilities related to both internal and international movements.

Recognizing the potential importance of climate change as a driver of humanitarian crises (including large-scale displacement), the members of the Interagency Standing Committee (IASC) for coordination, policy development and decisionmaking on humanitarian assistance established a task force on climate change. The IASC was created in 1992 through Resolution 46/182 of the General Assembly, with members drawn from the United Nations, the Red Cross and Red Crescent movement, the IOM and key nongovernmental humanitarian organizations. The IASC taskforce on climate change leads the preparation of high-quality analytical inputs to the United Nations Framework Convention on Climate Change (UNFCCC) process, and provides guidance as appropriate to the IASC on integrating climate risk management into agency policies, operations and relevant IASC guidelines and tools.

The Advisory Group on Climate Change and Human Mobility, comprised of academic and humanitarian institutions and coordinated by UNHCR, was formed in 2013 to serve as a conduit for translating knowledge into policies that consider the protection of people on the move. While serving a useful role in providing longerterm recommendations, the advisory group has had limited success in influencing the outcomes of the 2015 negotiations in Paris (COP 21). As its recommendations remain relevant, they are worthy of extended examination.

The Advisory Group called for human mobility to be addressed in all its forms (displacement, migration, planned relocation), and considered in policies that take into account the full range of societal impacts (mitigation, adaptation, and loss and damage). It highlighted the needs of migrants, refugees and people displaced internally or across borders, and called on Parties to " [r]ecognize that safeguards should be adopted to prevent and reduce the displacement of populations and its negative impacts, in the context of climate change mitigation and adaptation projects and policies (Advisory Group on Climate Change and Human Mobility 2015)."

The Advisory Group strongly encouraged states party to UNFCCC to take measures, including in their National Adaptation Plans, to prevent and reduce internal 
and cross-border displacement in close consultation with communities at risk of displacement. Among the efforts governments could make would be increasing resilience among displaced persons and host communities, and formulating participatory, dignified and sustainable responses. Crucially, the Advisory Group also recommended that States "[r]ecognize that human mobility measures within national and regional climate change adaptation plans, policies and strategies may require adaptation funding, including from the operating entities of the financial mechanism of the UNFCCC supporting both adaptation and loss and damage as well as other mechanisms" (Advisory Group on Climate Change and Human Mobility 2015).

The Advisory Group members reiterated the necessity for loss and damage policies to address climate change-related displacement and emphasized the "catalytic" role that the UNFCCC can play in supporting relevant organizations and frameworks that provide assistance and protection to persons displaced in the context of disasters and climate change. More specifically, the group called for a climate change displacement coordination facility to "serve as a forum for sharing experience and enhancing capacities to plan and implement climate adaptation measures that avoid displacement, facilitate voluntary migration, and encourage participatory and dignified planned relocation" (Advisory Group on Climate Change and Human Mobility 2015). Finally, the Advisory Group emphasized the importance of securing funding to support local, national and regional climate change adaptation, resilience building, and disaster risk management plans and activities. The Paris Conference of the Parties to the UNFCCC resolved to establish a taskforce to take on some of the responsibilities outlined in the recommendation for a displacement coordination facility but did not provide for the financing mechanism that the Advisory Group proposed.

On a more operational level, there is no designated organization to assist and protect those who move in the context of climate change. UNHCR has clear responsibility for refugees and those who are internally displaced by conflict, but it does not have responsibility for those displaced by natural hazards. The organization has nevertheless been drawn into providing assistance during several notable natural disasters, such as the Tsunami in Indonesia, Sri Lanka and Somalia (2004), Cyclone Nargis in Burma (2008), China's earthquake (2008), floods in Pakistan, Bangladesh and Myanmar/Burma (2010), and the Nepal earthquake in 2015. In many of these cases, UNHCR was already providing aid to conflict-induced refugees and internally displaced persons. IOM has responsibility for camp management and, on a case by case basis, protection of those displaced by natural hazards. It has also played an important role in stimulating research on environmental migration, displacement and planned relocation. The role of both organizations is limited, however, particularly as compared to UNHCR's mandate for protection of refugees, because of the absence of a legally binding convention that spells out the rights of those whose mobility is affected by climate change and other environmental shocks. 


\section{$5 \quad$ New Initiatives to Address Protection Gaps}

Given the dearth of legal, policy and institutional frameworks at the international, regional or national level specifically focused on the impacts of climate and other environmental changes on human mobility, a number of initiatives have been launched to promote guidelines that would be applicable in these situations. Sir Peter Sutherland (2016), the Special Representative of the Secretary General on International Migration, has dubbed these efforts mini-multilateralism - that is, efforts by states to develop non-binding guidance based on existing principles and effective practices. The success of the Guiding Principles on Internal Displacement in shifting perceptions and practices in countries throughout the world (including the promulgation of a regional convention in Africa) is the backdrop for these efforts. This section discusses two such initiatives that pertain to displacement, migration and planned relocation in the context of natural disasters and the slow onset effects of climate change: 1) the Nansen Initiative and its successor, the Platform on Disaster Displacement; and 2) the Migrants in Countries in Crisis (MICIC) initiative.

\subsection{The Nansen Initiative and the Platform on Disaster Displacement}

The Nansen Initiative, ${ }^{14}$ was launched in 2011 at a Ministerial Conference commemorating the $60^{\text {th }}$ anniversary of UNHCR's founding and adoption of the 1951 Refugee Convention. The aim was to develop an agenda for improving protection of people displaced cross borders by natural disasters and the slow onset effects of climate change. The impact of climate change on displacement had long been a concern to António Guterres, then the High Commissioner. As early as 2007, he gave voice to his concerns:

When we consider the different models for the impact of climate change, the picture is very worrying. The need for people to move will keep on growing. One need only look at East Africa and the Sahel region. All predictions are that desertification will expand steadily. For the population, this means decreasing livelihood prospects and increased migration. All of this is happening in the absence of international capacity and political will to respond. (Guterres 2007)

The following year, Assistant High Commissioner for Protection Erika Feller summarized the dilemma before the UNHCR Executive Committee:

"New terminology is entering the displacement lexicon with some speed. The talk is now of 'ecological refugees,', 'climate change refugees,' the 'natural disaster displaced.' This is all a serious context for UNHCR's efforts to fulfill its mandate for its core beneficiaries. (...) The mix of global challenges is explosive, and one with which we and our

14 The initiative was named after Fridtjof Nansen, the famous explorer who was named High Commissioner for refugees by the League of Nations in 1921 and received the Nobel Peace Prize in 1922 for his work on behalf of refugees and displaced persons. 
partners, government and non-government, must together strike the right balance (Feller 2008)."

In an address before the Security Council in November 2011 - with famine and displacement in Somalia heavily on his mind - High Commissioner Guterres returned to the theme: "we should be addressing the more complex issue of the way in which global warming, rising sea levels, changing weather patterns and other manifestations of climate change are interacting with and reinforcing other global imbalances, so as to produce some very powerful drivers of instability, conflict and displacement" (Guterres 2011).

In the lead up to the Ministerial Conference, the organization commissioned new research on climate change and displacement. Preparatory meetings were held in Bellagio (UNHCR 2011a) and Oslo (The Nansen Conference 2011) to discuss gaps in the international response to the evolving phenomena. The June 2011 Oslo conference resulted in the Nansen Principles, which outlined core approaches for addressing both internal and international displacement. Recognizing that the Guiding Principles on Internal Displacement already covered those displaced by natural disasters and other environmental disruptions, the Nansen Principles urged action on cross border movements: "A more coherent and consistent approach at the international level is needed to meet the protection needs of people displaced externally owing to sudden-onset disasters. States, working in conjunction with UNHCR and other relevant stakeholders, could develop a guiding framework or instrument in this regard" (The Nansen Conference 2011: 5).

The initial hope was that governments would back reforms in the institutional arrangements, particularly for responding to natural disasters, in the Ministerial Conference. This would have helped clarify under which situations UNHCR should take leadership in assisting and protecting victims. Governments did not agree that UNHCR should become more systematically involved with those displaced by natural disasters or climate change. A number argued that UNHCR was already overwhelmed with the growing number of refugees and internally displaced persons. The Ministerial Conference instead gave very indirect acknowledgement of the problem:

"We note that today's challenges in providing protection and achieving solutions continue to be serious, interconnected and complex. (...) We will reinforce cooperation with each other and work with UNHCR and other relevant stakeholders, as appropriate, to deepen our understanding of evolving patterns of displacement and to agree upon ways to respond to the challenges we face in a changing global context" (UNHCR 2011b).

The Swiss and Norwegian governments did take up the call in the Nansen Principles for more attention to protection needs, pledging to fund an intergovernmental process that would examine the issue and make recommendations for enhancing protection in both acute emergencies and slow onset processes.

Switzerland and Norway asked Walter Kälin, formerly the Special Representative of the Secretary General on the human rights of internally displaced persons and 
one of the principal architects of the Guiding Principles on Internal Displacement, to take on the leadership of the initiative, serving as the Chair's Envoy. The Nansen Initiative was clear in stating, however, that it did "not seek to develop new legal standards, but rather to build consensus among states on the elements of a protection agenda, which may include standards of treatment." (The Nansen Initiative 2017) There was no expectation that the process would lead to a set of guiding principles on cross-border displacement that would be equivalent to the ones developed for internally displaced persons. Rather, the Nansen Initiative sought to identify existing practices that complement refugee and other humanitarian protection regimes in use by countries in protecting those who are displaced by natural disasters and other forms of environmental change.

The initiative also differed from the Guiding Principles process in that it was state-led, rather than UN-led. It was governed by a Steering Committee, chaired by Switzerland and Norway, and included Australia, Bangladesh, Costa Rica, Germany, Kenya, Mexico and the Philippines. A Consultative Committee ${ }^{15}$ was formed to bring the expertise of representatives from international organizations dealing with displacement and migration issues, climate change and development, researchers, think tanks and non-governmental organizations to bear. A group of "Friends of the Initiative" allowed other governments to provide advice and remain informed of the deliberations. Finally, a secretariat supported the work of the initiative. The main fact-finding activities were a series of regional consultations to pull together evidence about the impacts of natural disasters and climate change on displacement and to solicit the views of governments and civil society. The secretariat also distilled the lessons of research for the initiative's consideration and commissioned background papers on a number of topics.

The Agenda for Protection, adopted as the outcome of the Nansen Initiative, focuses on three principal areas of action. The first is to improve the collection of data and to enhance knowledge on cross-border disaster-induced displacement. More specifically, the agenda recommends improvements in the collection, consolidation and analysis of "gender- and age-disaggregated data regarding the overall number of people displaced in disaster contexts, both internally and across international borders, based on clear criteria and effective methods" (The Nansen Initiative 2015: 45). It also calls for new "methodologies to identify those at risk of being displaced in disaster contexts, including across international borders" and new research to "determine to what extent men and women already rely on migration as a strategy to cope with the effects of natural hazards and the effects of climate change, and what lessons can be learned for improving the benefits of migration and addressing related protection risks" (The Nansen Initiative 2015: 45). Finally, it emphasizes the need for additional data and analysis of planned relocation processes in the context of disasters and effects of climate change.

$\overline{15}$ The author was a member of the Consultative Committee. 
The second area of the agenda focuses on "humanitarian protection measures for cross-border disaster-displaced persons, including mechanisms for lasting solutions" (The Nansen Initiative 2015: 44). This section is most pertinent to the development of measures to complement and augment protection of those displaced by environmental factors. These measures include ones related to the admission of disaster displaced persons from abroad as well as those preventing the return of displaced persons to countries experiencing natural disasters and the effects of climate change. The agenda points to the need for new legal instruments and policies that would, for example, grant "temporary entry and stay for cross-border disaster-displaced persons, such as through the issuance of humanitarian visas or other exceptional migration measures" (The Nansen Initiative 2015: 26).

The Nansen Initiative emphasized that governments could use existing legal frameworks, such as existing temporary labor migration and humanitarian admissions programs, more creatively to permit entry of those needing protection. It identified a number of examples in current practice (The Nansen Initiative 2015):

- Granting visas that authorize travel and entry upon arrival for people from disaster-affected countries, or temporarily suspending visa requirements;

- Prioritizing and expediting the processing of regular migration categories for foreigners from affected countries following a disaster, or waiving certain admission requirements for such categories;

- Relying upon regular (sub-)regional or bilateral free movement schemes to permit the temporary entry and stay of disaster displaced persons, and providing for the suspension of documentation requirements in disaster situations, recognizing that such persons may not possess, or have lost and are unable to acquire documentation normally required;

- Granting temporary entry and stay for cross-border disaster-displaced persons, such as through the issuance of humanitarian visas or other exceptional migration measures;

- Granting entry and temporary stay for a group or "mass influx" of crossborder disaster- displaced persons;

- Developing transhumance agreements to facilitate the cross-border movement of pastoralists and their livestock, particularly in situations when drought endangers the health and lives of humans and animals;

- Reviewing asylum applications of and granting refugee status or similar protection under human rights law to displaced persons in disaster contexts who meet the relevant criteria under applicable international, regional, or national law;

- Exploring at sub-regional and regional levels, where relevant, whether and under what circumstances regional instruments on refugee, and similar protection under human rights law, can and should be interpreted as applying to cross-border disaster-displacement situations; and

- Reviewing and harmonizing existing humanitarian protection measures at sub-regional and regional levels. 
The Agenda for Protection recognized, however, that these measures are not consistently implemented. Instead, they are "largely unpredictable, because they generally rely upon the discretionary power of relevant authorities as opposed to a legal obligation to admit or permit the stay of disaster displaced persons" (The Nansen Initiative 2015: 28).

Nansen also identified examples of mechanisms that were complements to the refugee non-refoulement standard. The effective practices in this regard include:

- Providing such persons with humanitarian protection measures such as suspending their deportation or extending or changing their existing migration status on humanitarian grounds if they would experience extreme hardship as a consequence of the disaster in case of return to the country of origin; or their country of origin has declared a disaster and is temporarily unable to manage the return of its citizens for reasons related to the disaster; and

- Providing persons eligible for humanitarian protection measures with adequate information on the possibility to benefit from such protection, and their rights and responsibilities once such protection has been granted.

The third set of recommendations is aimed at strengthening the management of disaster displacement risk in the country of origin so that those affected by natural disasters and the effects of climate change would not need to cross international borders. These include

"integrating human mobility within disaster risk reduction and climate change adaptation strategies, and other relevant development processes; ... improving the use of planned relocation as preventative or responsive measure to disaster risk and displacement; and ... ensuring that the needs of IDPs displaced in disaster situations are specifically addressed by relevant laws and policies on disaster risk management or internal displacement" (The Nansen Initiative 2015: 44).

Finally, the agenda notes that legal migration can prevent displacement since it allows people to move in a safe and orderly manner.

The Agenda was endorsed by 109 governmental delegations during a global multi-sectoral consultation in October 2015. More than 360 participants from governments, international organizations, academic institutions and civil society attended. That so large a number of governments endorsed the Agenda was impressive. Those who spoke at the consultation noted the utility of the agenda and the flexibility of governments to adopt its recommendations in accord with national law.

Subsequently, the German government took on the chairmanship of the process, announcing the Platform on Disaster Displacement (PDD) in May 2016 at the World Humanitarian Summit in Istanbul. The PDD has four main goals in furthering the Agenda for Protection. First, it seeks to address knowledge and data gaps. The longterm goal is to produce "global information management, analysis, tracking of trends and reporting regarding cross-border disaster-displacement, including on its root causes" (Platform on Disaster Displacement 2016a). In the short- to medium-term, the aim is to help ensure the inclusion of displacement in post-disaster needs and damage assessment tools and methodologies and in national censuses; strengthen 
risk mapping and forecasting modelling to identify vulnerable populations at risk of displacement and to better understand existing and emerging displacement risk drivers; and commission new research, as needed, to fill information gaps.

The second aim is to promote policy and normative development to fill gaps in protection, as outlined in the protection agenda. In keeping with the Nansen perspective, the focus is not on international conventions but rather with law and policy at the regional and national level. The PDD intends to work with regional consultative processes to develop guidance for countries on norm development, referencing the "Guide to Effective Practices on Admission and Stay for Persons Moving across Borders in the Context of Disasters" produced by the Nansen Initiative and Regional Conference on Migration (RCM) in Central and North America (Platform for Disaster Displacement 2016b). It will strive to support “legal and policy development at domestic and regional level and support the development of bilateral and regional frameworks regarding admission, stay and non-return of cross-border disaster-displaced persons" (Platform for Disaster Displacement 2016b).

The third aim flows naturally from the second area for the PDD. The aim is to enhance the use of effective practices identified by the Nansen Initiative. The focus is on humanitarian protection measures, such as policies that provide admission and temporary relief from removal for disaster displaced persons. Other practices that the PDD will promote include consideration of displacement in national, bilateral and regional contingency plans, disaster risk management and humanitarian response plans. It will also enhance use of options, such as planned relocation and voluntary migration, which are designed to reduce the likelihood that people will be displaced by natural hazards or the slow-onset impacts of climate change (Platform on Disaster Displacement 2016c).

Mainstreaming disaster-induced displacement across sectors, mandates and areas of expertise related to its multi-causality is the fourth aim of the PDD. This area stems from recognition that a "key gap and challenge highlighted by the Nansen Initiative is the need to bring together and link multiple policy and action areas that to date have been uncoordinated in order to better address cross-border disasterdisplacement and its root causes." To achieve this aim, the PDD will work with states as well as stakeholders from multiple sectors and disciplines. It will also coordinate with other initiatives, such as those commissioned with follow-up to the Sendai Framework on Disaster Risk Reduction, the UNFCCC Warsaw International Mechanism for Loss and Damage's Task Force on Displacement, and the follow-up to the World Humanitarian Summit.

\subsection{Migrants in Countries in Crisis}

The origins of the MICIC Initiative are similar to Nansen, whose success influenced its development. Sir Peter Sutherland, the Special Representative of the Secretary General, played the role that High Commissioner Guterres did in urging governments to fill the protection gap for non-nationals caught in acute emergencies resulting from conflict and natural disaster. The mass displacement of migrant workers in Libya during the 2011 conflict, followed by similar conflict-related crises in 
Cote d'Ivoire and Syria, in addition to the natural disasters in Japan, Thailand, and the United States that affected millions of non-nationals, generated substantial interest among governments, civil society and the private sector. In support of Sir Peter and with funding from the MacArthur Foundation, Georgetown University's Institute for the Study of International Migration commissioned a paper outlining the protection gaps (Koser 2014) and produced desk studies of the major crises involving displacement of non-nationals.

The call for action was met with a positive response by the United States and the Philippines. In her plenary statement at the 2013 High Level Dialogue on Migration and Development, Assistant Secretary Anne Richard, thanking Sir Peter and noting the seriousness of the problem, pledged on behalf of the United States to chair what became the MICIC initiative. She used language similar to Nansen's in describing the initiative: "I envision a State-led process aimed at examining the responsibilities of different actors in these crisis situations" (Richard 2013). A working group was subsequently named; in addition to the US and the Philippines, Australia, Bangladesh, Costa Rica, Ethiopia, and the European Commission (EC) also served on it as did IOM, UNHCR, the International Centre for Migration Policy Development (ICMPD), and ISIM.

$\mathrm{MICIC}$ also worked in similar ways to Nansen. A grant from the United States established a secretariat based at IOM; the EC funded regional consultations and the US and Australia supported consultations with civil society and the private sector, as well as members and friends of the Intergovernmental Consultation on Migration, Refugees and Asylum Seekers. The EC also supported a research program that examined the longer-term impacts of the crises on migrants and the US supported capacity building for countries experiencing the impacts of these crises.

The results of the consultations and research contributed to a set of principles, guidelines and effective practices that were presented on June 15, 2016 at the United Nations. The principles focused on core rights and responsibilities. The duty to save lives in conflict and disasters is the first responsibility; as such, the humanitarian principles of neutrality, impartiality and independence should govern responses to migrants in these crisis situations. To ensure effective protection, the principle of non-discrimination, particularly by immigration status, when lives are at risk permeates the recommendations. The principles and resulting guidelines emphasize that states have primary responsibility but that other stakeholders, including nonnationals themselves, play an important role in ensuring protection. In that respect, Principle 6 states clearly that "[m]igrants are rights holders and capable actors, resilient and creative in the face of adversities, not merely victims or passive recipients of assistance" (MIC/C 2016: 16).

The guidelines are described as "targeted suggestions, organized by theme, that identify in broad terms the actions needed to better protect migrants in countries experiencing crises. States, private sector actors, international organizations, and civil society can use the Guidelines to inform and shape crisis preparedness, emergency response, and post-crisis action" (MIC/C 2016: 19). They are organized around the phases of crises: pre-, during- and post-crisis. Each is elaborated with concrete practices that would aid their implementation. The most detail is provided 
on pre-crisis emergency preparedness since this is the phase in which much can be done to lay the groundwork for effective action during crises. The guidelines recognize, however, that crises often take on lives of their own and that needs and contexts depart from even the best laid plans. As such, they recommend continual assessment of the situation and flexibility to adapt and innovate as needed during the emergency response period. They also take into account that the post-crisis stage requires special attention to the long-term needs of migrants displaced by conflict and disasters as well as to the needs of communities to which they may need to relocate.

While many of the issues raised in MICIC apply equally in conflicts and natural disasters, the initiative did make distinctions where applicable. A discussion brief prepared for $\mathrm{MICIC}$ observed that one of the most important differences is in the role of national authorities in the affected countries. Whereas in conflicts, the national authorities may be part of the problem in protecting citizens and non-citizens alike, "in most cases of natural disasters, governments are willing to assist all persons on their territory requiring emergency assistance, including non-citizens. They may not have the capacity, however, to carry out all of the tasks needed to protect citizens and non-citizens alike and may require the assistance of other actors (Martin 2016)" As a result, MICIC emphasized integration of the needs and capabilities of migrants into existing and disaster risk reduction, early warning, emergency preparedness and emergency response systems, with particular attention to migrant-specific issues such as their ability to read and comprehend the host language. It also urged states to institute awareness-raising programs for migrants about prevention, preparedness, and emergency response procedures in host countries. Recognizing that some migrants may leave post-natural disaster, while others enter affected areas, $\mathrm{MICIC}$ also recommended measures to prevent the exploitation of migrants working in post-disaster reconstruction jobs by providing prevailing wages, monitoring work conditions, providing safety equipment as needed, and enforcing laws against human smuggling, trafficking in persons, occupational health and safety, and other labor violations (MIC/C 2016).

\section{Conclusion}

This review of trends in environmental change and human mobility identifies some areas of research and policy development that are needed to respond more effectively. It is not meant to be exhaustive in laying out a research or policy agenda. In the area of research, more attention is needed to improve the evidence base on the environmental determinants of migration, displacement and planned relocation; the multi-faceted ways in which environmental factors relate to the many other causes of population movements in the cases of migration, displacement and planned relocation; and the impact of migration, displacement and planned relocation undertaken in the context of environmental change on the well-being of migrants, communities of origin, and communities of destination. As compared to even ten years ago, there has been great progress in filling the gaps in evidence and knowledge of the 
mobility implications of environmental change generally and climate change more specifically. With the increasing attention of governments to these issues, there is reason for cautious optimism that this progress will continue.

At the legislative and policy level, there are also grounds for cautious optimism. The Nansen and MICIC initiatives represent new ways in which governments and other stakeholders are attempting to address persistent protection gaps for those affected by environmental change. There are four reasons for optimism. First, unlike earlier efforts that focused primarily on the adoption of binding international conventions, these initiatives are less formal, more ad hoc and less binding. They are more pragmatic, given the reluctance of states to adopt and ratify new binding instruments related to movements of people. Promulgation of the Guiding Principles on Internal Displacement has proven to be a highly effective way to gain visibility and improved protection for a population that had not previously received sufficient attention. The Guiding Principles have been recognized widely as applicable to a broad range of persons forced to leave their homes because of events beyond their control. They have broad support, as witnessed by the 2005 World Summit's entreaty to states and international organizations to implement them. Many individual countries have incorporated them into national law and the African Union has promulgated a binding convention based on them.

Second, because states are leading these efforts, there is a built-in constituency for ensuring their implementation. The Nansen Initiative has been succeeded by the Platform for Disaster Displacement, which was announced at the World Humanitarian Summit in May 2016. The platform will follow up on Nansen and implement the recommendations of the Protection Agenda by building "partnerships between policymakers, practitioners and researchers and constitute a multi-stakeholder forum for dialogue, information sharing as well as policy and normative development." The Chairs of the MICIC initiative have pledged a similar follow-up process, with the continuation of the secretariat's capacity-building and other activities.

Third, these processes have been highly inclusive in terms of regional scope and participation. Members of the steering/working groups have come from all regions. Regional variations have been solicited in consultations that brought together governments, civil society, the private sector, international organizations and the research community. The resulting recommendations have been vetted with multiple stakeholders although responsibility for issuing them ultimately rested with the state leads.

Finally, the ad hoc nature of these processes allows them to address emerging issues and concerns more effectively than more formal mechanisms that are often tied to specific mandates. MICIC was criticized by some civil society organizations and a few governments at its inception because its focus was restricted to migrants affected by conflict and natural disasters. The critics urged the working group to address the problems of those in crises stemming from other causes - for example, irregular migrants stranded by smugglers en route to their destination. Fearing that it would be more difficult to build consensus around solid recommendations on other populations, the working group held fast. However, MICIC made a clear statement that "Notwithstanding the limited scope of the MICIC initiative, it is hoped and ex- 
pected that its outcomes will be useful for States and other stakeholders in addressing a broader range of migration scenarios." In fact, many of the recommendations in the MICIC guidelines do apply more broadly and civil society groups could readily use them to advocate for others moving in the context of environmental change. Most notably, Principle 2 states: "As human beings, all migrants are entitled to human rights, regardless of their immigration status. At all times, the human rights of migrants should be respected, protected, and fulfilled in a non-discriminatory manner and in accordance with applicable international law" (MICIC 2016: 15). Members of the working group have also been supportive of the recommendation in the Secretary General's report for the High Level Meeting on Large-Scale Migration and Refugee Movements to form a working group similar to $\mathrm{MICIC}$ on vulnerable migrants more generally.

This is not to say that the ad hoc, non-binding nature of the processes is without problems. As has been seen with regard to internally displaced persons, protection is still highly dependent on the willingness of states to implement the guiding principles and the international community to intercede when states are unwilling or unable to fulfill their responsibilities. Enhancing protection of those displaced by natural disasters and the impacts of climate change will require sustained attention. Mechanisms such as the Nansen and MICIC initiatives, and their follow-up, are promising ways to foster greater attention to the protection gaps and practical solutions to improve the lives of millions of people affected by crises. In the long term, however, they will only be as effective as the willingness of states and other stakeholders to implement the recommendations and offer protection on a nondiscriminatory basis to all who are affected by the acute and slow-onset effects of climate change.

\section{References}

Adger, W. Neil et al. 2014: Human security. In: Field, Christopher B. et al. (Eds.): Climate Change 2014: Impacts, Adaptation, and Vulnerability. Part A: Global and Sectoral Aspects. Contribution of Working Group II to the Fifth Assessment Report of the Intergovernmental Panel on Climate Change. Cambridge/New York: Cambridge University Press: 755-791.

Advisory Group on Climate Change and Human Mobility 2015: Human Mobility in the Context of Climate Change UNFCCC - Paris COP 21: Recommendations from the Advisory Group on Climate Change and Human Mobility.

Birk, Thomas; Rasmussen, Kjeld 2014: Migration from Atolls as Climate Change Adaptation: Current Practices, Barriers and Options in Solomon Islands. In: Natural Resources Forum 38,1: 1-13 [doi: 10.1111/1477-8947.12038].

Black, Richard et al. 2011: The Effect of Environmental Change on Human Migration. In: Global Environmental Change 21: S3-S11 [doi: 10.1016/j.gloenvcha.2011.10.001].

Brookings Institution; Georgetown University; UNHCR 2014: Planned Relocations, Disasters and Climate Change: Consolidating Good Practices and Preparing for the Future. Washington DC: Brookings Institution. 
Brookings Institution; Georgetown University; UNHCR 2015: Guidance on Protecting People from Disasters and Environmental Change through Planned Relocation, Washington DC: Brookings Institution.

Bylander, Maryann 2016: Cambodian Migration to Thailand: The Role of Environmental Shocks and Stress. Washington DC: World Bank.

Cernea, Michae/ 1997: The risks and reconstruction model for resettling displaced populations. In: World Development 25,10: 1569-1587 [doi: 10.1016/S0305-750X(97)00054-5].

Cernea, Michael 2005: Understanding and preventing impoverishment from displacement: Reflections on the state of knowledge. In: Journal of Refugee Studies 8,3: 245264 [doi: 10.1093/jrs/8.3.245].

Connor, Phillip 2016: Number of Refugees to Europe Surges to Record 1.3 Million in 2015. Pew Research Center [http://www.pewglobal.org/2016/08/02/number-of-refugees-to-europe-surges-to-record-1-3-million-in-2015, 04.10.2017].

Dun, Olivia 2011: Migration and Displacement Triggered by Floods in the Mekong Delta In: International Migration 49: 200-223 [doi: 10.1111/j.1468-2435.2010.00646.x].

de Sherbinin, Alex; Warner, Koko; Ehrhart, Charles 2011: Casualties of Climate Change. In: Scientific American: 64-71 [doi: 10.1038/scientificamerican0111-64].

De Wet, Chris J. 2006: Development-induced Displacement: Problems, Policies, and People. Oxford: Berghahn Books.

Etzold, Benjamin et al. 2014: Clouds Gather in the Sky, but no Rain Falls. Vulnerability to Rainfall Variability and Food Insecurity in Northern Bangladesh and its Effects on $\mathrm{Mi}$ gration. In: Climate and Development 6,1: 18-27 [doi: 10.1080/17565529.2013.833078]

Feller, Erika 2008: Statement by UNHCR Assistant High Commissioner for Protection at the $42^{\text {nd }}$ Meeting of the Standing Committee, Agenda Item 3 (24 June 2008).

Foresight Project: Migration and Global Environmental Change 2011: Final Project Report. London: The Government Office for Science.

Geddes, Andrew; Sommerville, Will 2013: Migration and Environmental Change: Assessing the developing European approach. Policy Brief Series 2, Migration Policy Institute Europe, May 2013.

Georgetown University; UNHCR; IOM 2016: A toolbox: Planning Relocations to Protect People from Disasters and Environmental Change. Washington DC: Georgetown University.

Ginetti, Justin 2015: Disaster-Related Displacement Risk: Measuring the Risk and Addressing its Drivers. International Displacement Monitoring Centre.

Gray, Clark; Mueller, Valerie 2012: Drought and population mobility in rural Ethiopia. In: World Development 40,1: 134-145 [doi: 10.1016/j.worlddev.2011.05.023].

Guterres, António 2007: Keynote Speech by UN High Commissioner for Refugees, Third Symposium on Corporate Social Responsibility and Humanitarian Assistance, Tokyo, 26 November 2007 [http://www.unhcr.org/admin/ADMIN/476132d911.html, 11.10.2017].

Guterres, António 2011: Statement by UNHCR High Commissioner for Refugees at the United Nations Security Council Briefing "Maintenance of International Peace and Security: "New Challenges to International Peace and Security and Conflict Prevention", 23 November 2011 [http://www.unhcr.org/admin/hcspeeches/4ee21edc9/statementmr-antonio-guterres-united-nations-high-commissioner-refugees.html, 11.10.2017]. 
Hugo, Graeme 2011: Future Demographic Change and its Interactions with Migration and Climate Change. In: Global Environmental Change 21, Supplement 1: S21-S33 [doi: 10.1016/j.gloenvcha.2011.09.008].

ICPP (Intergovernmental Panel on Climate Change) 2014: Summary for policymakers. In: Field, Christopher B. et al. (Eds.): Climate Change 2014: Impacts, Adaptation, and Vulnerability. Part A: Global and Sectoral Aspects. Contribution of Working Group II to the Fifth Assessment Report of the Intergovernmental Panel on Climate Change. Cambridge/New York: Cambridge University Press: 1-32.

IFRC (International Federation of Red Cross and Red Crescent Societies) 2012: World Disasters Report 2012: Focus on forced migration and displacement. Geneva: IFRC.

IOM (International Organization for Migration) 2007: Discussion Note: Migration and the Environment. MC/ INF/288, prepared for the Ninety-fourth Session of the IOM Council, 27-30 November 2007, Geneva.

Jülich, Sebastian 2011: Drought Triggered Temporary Migration in an East Indian Village. In: International Migration 49,s1: e189-e199.

Kelley, Colin P. et al. 2015: Climate Change in the Fertile Crescent and Implications of the Recent Syrian Drought. In: Hoskins, Brian John (Ed.). Proceedings of the National Academy of Sciences of the United States of America 112,11: 3241-3246 [doi: 10.1073/ pnas.1421533112].

Kniveton, Dominic; Smith, Christopher; Wood, Sharon 2011: Agent-Based Model Simulations of Future Changes in Migration Flows for Burkina Faso. In: Global Environmental Change 21, Supplement 1: S34-S40 [doi: 10.1016/j.gloenvcha.2011.09.006].

Koser, Khalid 2014: Protecting non-citizens in situations of conflict, violence and disaster. In: Martin, Susan; Weerasinghe, Sanjula; Taylor, Abbie: Migration and Humanitarian Crises: Causes, Consequences and Responses. NY: Routledge Books.

Lopez, Aurelie 2007: The Protection of Environmentally-Displaced Persons in International Law. In: Environmental Law 37,2: 365-409.

Martin, Susan 2012: Environmental change and migration: legal and political frameworks. In: Environment and Planning C: Government and Policy 30,6: 1045-1060 [doi: 10.1068/c1242j].

Martin, Susan F. 2016: New Models of International Agreement for Refugee Protection. In: Journal of Migration and Human Security 4,3): 60-75 [doi: 10.14240/jmhs.v4i3.62].

MICIC (Migrants in Countries in Crisis Initiative) 2016: Guidelines to Protect Migrants in Countries Experiencing Conflict or Natural Disaster. Geneva: IOM.

Neef, Andreas; Singer, Jane 2015: Development-induced displacement in Asia: conflicts, risks, and resilience. In: Development in Practice 25,5: 601-611 [doi: 10.1080/09 614524.2015.1052374].

Platform on Disaster Displacement 2016a: Address knowledge and data gaps [http:// disasterdisplacement.org/address-knowledge-and-data-gaps, 04.10.2017].

Platform on Disaster Displacement 2016b: Promote Policy and Normative Development in Gap Areas. Geneva [http://disasterdisplacement.org/promote-policy-and-normative-development-in-gap-areas, 04.10.2017].

Platform on Disaster Displacement 2016c: Enhance the use of identified effective practices. Geneva: Platform on Disaster Displacement [http://disasterdisplacement.org/ enhance-the-use-of-identified-effective-practices, 04.10.2017]. 
Platform on Disaster Displacement 2016d: Mainstream human mobility challenges across relevant action areas. Geneva: Platform on Disaster Displacement [http://disasterdisplacement.org/mainstream-human-mobility-challenges-across-relevant-actionareas, 04.10.2017]

Rademacher-Schulz, Christina; Schraven, Benjamin; Mahama, Edward Salifu 2014: Time Matters: Shifting Seasonal Migration in Northern Ghana in Response to Rainfall Variability and Food Insecurity. In: Climate and Development 6,1: 46-52 [doi: 10.1080/17565529.2013.830955].

Richard, Anne 2013: Remarks of Anne C. Richard. Assistant Secretary, Bureau of Population, Refugees, and Migration at the UN. High Level Dialogue on Migration and Development. New York City: October 2, 2013.

Shen, Shawn; Gemenne, François 2011: Contrasted Views on Environmental Change and Migration: The Case of Tuvaluan Migration to New Zealand. In: International Migration 49,s1: e224-e242 [doi: 10.1111/j.1468-2435.2010.00635.x].

Smith, Roy; McNamara, Karen E. 2014: Future Migrations from Tuvalu and Kiribati: Exploring Government, Civil Society and Donor Perceptions. In: Climate and Development 7,1: 47-59 [doi: 10.1080/17565529.2014.900603].

Stojanov, Robert et al. 2014: Migration as Adaptation? Population Dynamics in the Age of Climate Variability. Brno: Global Change Research Centre, Academy of the Sciences of the Czech Republic.

Sutherland, Peter D. 2016: Remarks by the Special Representative of the UN Secretary General on International Migration. Delivered at the UN DESA Coordination Meeting, 25 February 2016.

The Nansen Conference 2011: Climate Change and Displacement in the $21^{\text {st }}$ Century. Oslo, 5-7 June 2011 [http://www.unhcr.org/4ea969729.pdf, 04.10.2017].

The Nansen Initiative 2015: Agenda for the Protection of Cross-Border Displaced Persons in the Context of Disasters and Climate Change Volume I. Geneva: The Nansen Initiative [https://nanseninitiative.org/wp-content/uploads/2015/02/PROTECTIONAGENDA-VOLUME-1.pdf, 11.10.2017].

The Nansen Initiative 2017: About us. Geneva: The Nansen Initiative [https://www.nanseninitiative.org/secretariat/, 06.10.2017].

UNFCCC 2012: Report of the Conference of the Parties on its eighteenth session, held in Doha from 26 November to 8 December 2012, Addendum Part Two: Action taken by the Conference of the Parties at its eighteenth session [http://unfccc.int/resource/ docs/2012/cop18/eng/08a01.pdf, 04.10.2017].

UNFCCC 2016: Report of the Conference of the Parties on its twenty-first session, held in Paris from 30 November to 13 December 2015, Addendum Part two: Action taken by the Conference of the Parties at its twenty-first session [http://unfccc.int/resource/ docs/2015/cop21/eng/10a01.pdf, 04.10.2017].

UNHCR 2011a: Summary of Deliberations on Climate Change and Displacement in Bellagio. Geneva: UNHCR.

UNHCR 2011b: Ministerial Communique: Intergovernmental event at the ministerial level of Member States of the United Nations on the occasion of the $60^{\text {th }}$ anniversary of the 1951 Convention relating to the Status of Refugees and the $50^{\text {th }}$ anniversary of the 1961 Convention on the Reduction of Statelessness, HCR/MINCOMMS/2011/6, 8 December 2011 [http://www.unhcr.org/4ee210d89.pdf, 04.10.2017]. 
UNHCR 2017: UNHCR says death risk from starvation in Horn of Africa, Yemen, $\mathrm{Ni}-$ geria growing, displacement already rising [http://www.unhcr.org/afr/news/ briefing/2017/4/58ec9d464/unhcr-says-death-risk-starvation-horn-africa-yemen-nigeria-growing-displacement.html, 04.10.2017].

Warner, Koko et al. 2012: Evidence from the Frontlines of Climate Change: Loss and Damage to Communities despite Coping and Adaptation. UNU-EHS/Climate \& Development Knowledge Network. No. 9, November 2012 [https://collections.unu.edu/eserv/UNU:1847/pdf10584.pdf, 04.10.2017].

Warner, Koko; van der Geest, Kees 2013: Loss and damage from climate change: local-level evidence from nine vulnerable countries. In: International Journal of Global Warming 5,4: 367-386 [doi: 10.1504/IJGW.2013.057289].

Warner, Koko; Afifi, Tamer 2014: Where the Rain Falls: Evidence from 8 Countries on how Vulnerable Households use Migration to Manage the Risk of Rainfall Variability and Food Insecurity. In: Climate and Development 6,1: 1-17 [doi: 10.1080/17565529.2013.835707].

Weiss Fagen, Patricia 2013: Receiving Haitian Migrants in the Context of the 2010 Earthquake. Geneva: The Nansen Initiative.

Wrathall, David 2012: Migration Amidst Social-Ecological Regime Shift: The Search for Stability in Garífuna Villages of Northern Honduras. In: Human Ecology 40,4: 583-596 [doi: 10.1007/s10745-012-9501-8].

White, Gregory 2011: Climate Change and Migration. Oxford: Oxford University Press.

Prof. Dr. Susan F. Martin ( $₫)$. Georgetown University. Washington D.C., USA.

E-mail: martinsf@georgetown.edu

URL: http://explore.georgetown.edu/people/martinsf/ 


\section{Comparative Population Studies}

wWW.comparativepopulationstudies.de

ISSN: 1869-8980 (Print) - 1869-8999 (Internet)

\section{Published by}

Prof. Dr. Norbert F. Schneider

Federal Institute for Population Research D-65180 Wiesbaden / Germany

\section{(cc) BY-SA}

2017

\section{Managing Editor}

Frank Swiaczny

\section{Assistant Managing Editor}

Katrin Schiefer

\section{Copy Editor}

(Selected Articles in German)

Dr. Evelyn Grünheid

\section{Layout}

Beatriz Feiler-Fuchs

E-mail: cpos@bib.bund.de

\section{Scientific Advisory Board}

Paul Gans (Mannheim)

Karsten Hank (Cologne)

Johannes Huinink (Bremen)

Michaela Kreyenfeld (Rostock)

Marc Luy (Vienna)

Notburga Ott (Bochum)

Peter Preisendörfer (Mainz)

Nikola Sander (Groningen)

Zsolt Spéder (Budapest)

\section{Board of Reviewers}

Martin Abraham (Erlangen)

Laura Bernardi (Lausanne)

Hansjörg Bucher (Bonn)

Claudia Diehl (Konstanz)

Andreas Diekmann (Zurich)

Gabriele Doblhammer-Reiter (Rostock)

Jürgen Dorbritz (Wiesbaden)

Anette Eva Fasang (Berlin)

E.-Jürgen Flöthmann (Bielefeld)

Alexia Fürnkranz-Prskawetz (Vienna)

Beat Fux (Salzburg)

Joshua Goldstein (Berkeley)

Sonja Haug (Regensburg)

Hill Kulu (Liverpool)

Aart C. Liefbroer (The Hague)

Kurt Lüscher (Konstanz)

Emma Lundholm (Umeå)

Nadja Milewski (Rostock)

Dimiter Philipov (Vienna)

Roland Rau (Rostock)

Tomáš Sobotka (Vienna)

Jeroen Spijker (Barcelona)

Olivier Thévenon (Paris)

Helga de Valk (Brussels)

Heike Trappe (Rostock)

Michael Wagner (Cologne) 